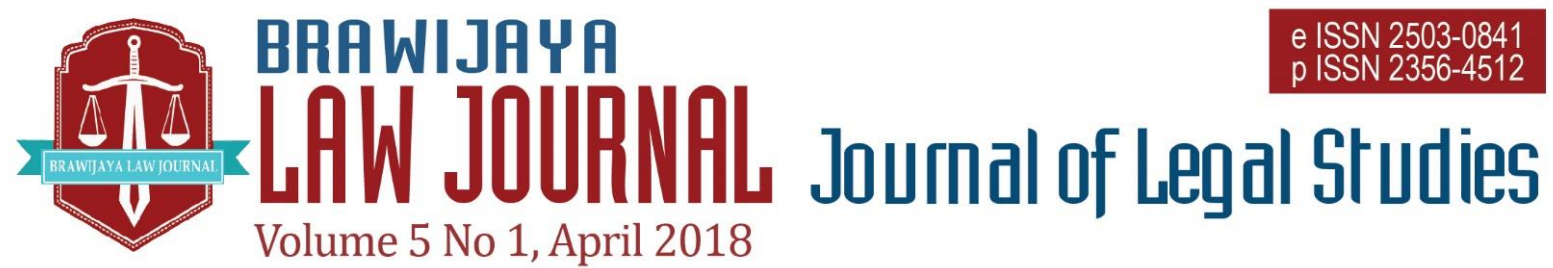

Nationally Accredited No. 32a/E/KPT/2017 Dated 26th April 2017

This work is licensed under a Creative Commons Attribution-NonCommercial 4.0 International License

\title{
Who's Law is it Anyway? \\ (A Comparison of Attitudes Towards Dispute Resolution in China and Taiwan, through Australian Eyes)
}

\author{
${ }^{1}$ Charlotte Ethel Smee \\ ${ }^{1}$ University of Wollongong, Australia \\ E-mail : charlottesmee9@gmail.com
}

Submitted : 2017-09-07 | Accepted : 2018-03-28

\begin{abstract}
This essay aims to address the gaps in research by exploring how non-legal cultural backgrounds and historical contexts can affect how mediation is received in different legal systems. While there is never a discussion of cultural attitudes contributing to the relative success of ADR methods, the comparison reveals just how important culture is when examining legal process. Different legal system results in different perception of justice and thus it is important to identify lesson learn from different experiences and incorporate them into each system to better facilitate dispute resolution in own system.

Case studies and legislation, as well as the study of how mediation processes are utilised effectively and are used to argue that culture is an important factor to consider when examining $A D R$ processes. In order to investigate the role of culture in mediation process, this paper uses comparative analyses of mediation process in Australia, China and Taiwan.
\end{abstract}

Keywords: Alternative Dispute Resolution, mediation, China, Taiwan, Australia, cultural attitudes, comparative study

\section{INTRODUCTION}

In Australia and the United States, the alternative dispute resolution ('ADR') mechanisms as legitimate alternatives to the court system were just accepted. Those countries are often held back from embracing mediatory techniques because of our obsession with justice over efficiency, and the fear of 'new' and unfamiliar processes. ${ }^{1}$ The biggest obstacle that ADR faces in the

\footnotetext{
${ }^{1}$ Peter Dwight, 'Commercial Dispute Resolution in Australia: Some Trends and Misconceptions' (1989) 1 Bond Law Review 1, 9.

2 Ibid, 2.
}

West is an 'ingrained attitude that an early approach to settlement is a sign of weakness' and a complete waste of time. ${ }^{2}$ On the other hand, the Chinese believed that 'the law was for barbarians', and an ideal society would 'never require extensive litigation or legislation'. ${ }^{3}$ Mediation was therefore the preferred method of dispute resolution, because mediation would preserve harmony for the collective good and sidestep the

\footnotetext{
Diana Yun-Hsien Lin, 'Civil Mediation in Taiwan: Legal Culture and the Process of Legal Modernisation' (2011) 6 University of Pennsylvania East Asia Law Review 191, 196.
} 
corrupt, inefficient court systems of old. ${ }^{4}$ These two drastically different viewpoints are not often placed together, because Western scholars and lawyers take an introspective view of their own legal systems, preferring to solve problems using familiar principles and processes.

While some Western scholars do recognise that 'forms of mediation can be traced back to sources in Ancient Greece, the Bible, traditional communities in Asia and Africa, and to the fourteenth Century English Mediators of Questions ${ }^{5}$; the development of modern and legitimate alternative dispute resolution processes are almost always attributed to Western thought and common law legal traditions. ${ }^{6}$ This is problematic because it oversimplifies the cultural context behind different legal systems, including those in the West. The West almost always credits itself with the invention of modern mediation, even where these kinds of processes have existed as the primary method of resolving disputes in China for centuries. This essay aims to explore how different attitudes towards ADR and litigation in different contexts have contributed to the ways that ADR processes have developed in China, Taiwan and Australia, as well as illustrating the unexpected similarities between the Taiwanese and Australian legal systems. Case studies and legislation, as well as the study of how mediation processes are utilised effectively and are used to argue that culture is an important factor to consider when examining ADR processes. In order to investigate the role of culture in mediation process, this paper uses comparative analyses

4 Jerome Alan Cohen, 'Chinese Mediation on the Eve of Modernisation' (1966) 54 California Law Review 1201, 1212.

5 Nadja Alexander, 'What's Law Got to Do With It? Mapping Modern Mediation Movements in Civil of mediation process in China, Australia, and Taiwan.

\section{LEGAL MATERIALS AND METHODS}

This type of research can be classified as normative reseach or legal research literature based heavily on legislations of three different countries.

Case studies and legislation, as well as the study of how mediation processes are utilised effectively and are used to argue that culture is an important factor to consider when examining ADR processes. In order to investigate the role of culture in mediation process, this paper uses comparative analyses of mediation process in Australia, China and Taiwan.

Legal materials used for this research varies from primary legal sources, which include relevant acts and also legislations of China, Australia as well as Taiwan.

\section{RESULTS AND DISCUSSIONS}

\section{Historical Development}

This section briefly overview historical development in alternative dispute resolution, specificaly mediation mechanism in three contries, which are China, Australia and Taiwan. The aim of this is to determine whether cultural tendency incluence country's approach in considering an alternative dispute resolution. It analyses how important culture is when examining legal process, including mediation as one of legal process.

\section{Imperial China: a shared history with the modern Taiwanese}

and Common Law Jurisdictions' (2001) 13 Bond Law Review 1, 1.

6 Ibid, 1-2. 
China before 1911 has a vast history, and it is difficult not to oversimplify its diverse influences and societies. Since the Qin dynasty it has been centralised, at least formally, under an imperial autocratic rule. During this time, the law was used as a tool to preserve the Emperor's power, rather than to protect individual rights and resolve disputes. ${ }^{7}$ This is important because it created a society in which common people distrusted the mechanisms of the law, and could not use it for their own purposes in the same way that it is used in modern Australia. Distrust, as well as the time and cost of travelling to the local magistrate that was often located only in the central city of a province, meant that the Chinese often preferred mediation methods outside the court system. This effect was accentuated by the structure of the system itself; when a complaint was brought before a magistrate his first task was to accept or reject the claim, and if accepted investigate the merits of the claim or, if rejected, he was to provide an opinion containing a statement persuading both parties to settle the matter between themselves based on the analysis provided by the magistrate. $^{8}$

This system was paired with the Confucian preference for mediation, which stems from the idea that the legal process of a society was not an achievement of civilisation 'but rather a regrettable

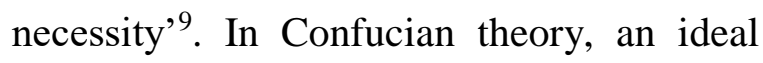
society would not require laws because its people would resolve disputes peacefully between themselves. A highly important Confucian teaching still very much present in China and Taiwan is the importance of social harmony and the resulting anti-lawsuit attitude. ${ }^{10}$ This attitude treated the use of the law to resolve disputes as the last resort, in that it would destroy the relationships between those involved in the dispute and force them to take their petty problems before the magistrate. Mediation was therefore a perfect alternative to the official court system that was not helpful or practical in the first place, and would avoid the embarrassment and punishment associated with even civil disputes. ${ }^{11}$

The emphasis on mediation was not really codified in the legislation of the Qing dynasty, the last dynasty before 1911, the only mention being in the Official Commentary to the Qing Code authorising certain rural leaders to reconcile disputes over 'petty matters' like property and domestic matters. ${ }^{12}$ It was instead found in the way that the Chinese people reacted to and used the courts in practice, reflecting both the Confucian sentiment and the dissatisfaction with the court system. The most extreme example of the anti-lawsuit attitude in action is the village where there was not a single lawsuit for more than a generation because of the influence of a village official who could ensure that disputes were resolved before they could be heard in a court. ${ }^{13}$ The influence of officials who acted in line with Confucian philosophy also had an overwhelming effect on the way that Chinese people resolved disputes, even though their attitudes were not cemented in Qing dynasty legislation.

Imperial China's court system, combined with Confucian anti-lawsuit
Yujun Feng, 'Legal Culture in China: A Comparison to Western Law' (2010) 16 Revue Juridique Polynesienne 115, 118.

8 Cohen, above n 4, 1211.

9 Ibid, 1201.

\footnotetext{
10 Lin, above n 3, 195.

11 Ibid, 195.

12 Cohen, above n 4, 1209.

13 Ibid, 1210.
} 
attitudes and officials who acted in accordance with this, fostered a culture in which mediation and other alternative dispute resolution methods flourished.

\section{Australia: child of Mother Britain}

Australia's legal system is inherited straight from the common law tradition in Britain, exported to us by the Imperialist colonisers in 1777 and effectively erasing any kind of legal system that existed before that. This does not mean that Australia is an exact copy of Britain, just as the US is not, but instead means that Australia operate on the principles set out by common law judges at the time of the King's Courts. ${ }^{14}$ The English system was based on the idea of impartiality, and developed from humble beginnings in the $12^{\text {th }}$ century as a body of separate adjudicators who resolved disputes. ${ }^{15}$ By Henry VIII, the common law courts alone had cumbersome and clogged and the Courts of Chancery were developed. These were the mediaeval English equivalent to mediation, but soon became just as overworked as the common law courts. ${ }^{16}$ The English example emphasised impartiality and formality, and this is problematic for mediation because it effectively sidesteps the official process of the court system. By opting for a separate court for equitable and civil disputes that utilised only a small range of the King's discretion, the English set a precedent of formality and due process that ensured that disputes were properly managed.

\footnotetext{
14 Melissa Hanks, 'Perspectives on Mandatory Mediation' (2012) 35 University of New South Wales Law Journal 929, 944.

15 Courts and Tribunals Judiciary, History of the Judiciary (2017) <https://www.judiciary.gov.uk/about-thejudiciary/history-of-the-judiciary/>

16 Ibid.
}

Australia then took this system and developed it to match our own context and legal culture. This culture is less defined than that of Britain, and is often made up of a mix of other systems altered to suit our specific problems. 'A look at The Law Reports of the Commonwealth illustrates the high degree of comparative law borrowing that still happens in the world-wide family of Commonwealth courts ${ }^{17}$, and this has contributed to the way that Australia has so uniquely developed its mediation processes ahead of the rest of the Western legal world. Australia's unique position as a common law country in the Pacific basin, that has some kind of uniform federal system, creates a steady foundation for modern mediation. This is somewhat restrained by the attitudes inherited from an English common law system; adversarialism, concern that ADR methods do not afford formality expected from courts, and ultimately that anything outside a court is not binding on a party and therefore useless. In terms of mediation, Australia is a world leader for the West, drawing ever so subtly from the East.

\section{Taiwan: not just another province of China}

While Taiwan inherited the Chinese legal system when the Nationalists fled the mainland in 1949, there were a few legal systems in place beforehand. Taiwan was modernised much earlier than China when Japan assumed control over Taiwan and implemented its own modern codes. ${ }^{18}$ These

\footnotetext{
${ }^{17}$ Michael Kirby 'ADR and Different Legal Cultures' (Speech delivered at the Arbitrator's and Mediator's Institute of New Zealand, Institute of Arbitrators and Mediators Australia Conference, Christchurch NZ, 6 August 2010) <http://www.michaelkirby.com.au/images/stories/ speeches/2000s/2010_Speeches/2476-AMINZ-IAMA-CONF-2010-CHRISTCHURCH-NZ.pdf>

18 Lin, above n 3, 199.
} 
modern codes were modelled on the German civil system, which brought with it assumptions of formality similar to those in England and other common law countries. However, the Japanese recognised the customs of both the indigenous Taiwanese people and the Han Chinese when dealing with family and other civil disputes - which preserved the heavy Confucian influence over mediation and alternative dispute resolution processes. ${ }^{19}$ It was, however, still controlled by the Japanese who exerted their control through administrative means, for example the 1904 Civil Disputes Mediation Law punished non-appearance at mediation with visits to the police station and the imposition of a fine. ${ }^{20}$ The presence of the Japanese gave the Taiwanese the opportunity to access courts very differently to the people in Qing dynasty China, and this meant that by the 1920s the people had become 'accustomed to using modern courts to resolve civil disputes, and the number of civil lawsuits eventually surpassed that of administrative mediation'. ${ }^{21}$ Taiwanese people therefore had a more positive attitude to the courts than the Chinese, thanks to the eager promotion of the modern system brought by the Japanese. ${ }^{22}$

Taiwan is similar to Australia, in that it is a blend of Western and Eastern cultures although it begins from the East and has moved toward the West. Taiwan's unique position as 'one land with two flags', ${ }^{23}$ reflects its complicated history and allows it to be receptive to many influences from ADR movements in the West, but also to the

\footnotetext{
19 Ibid, 199.

20 Ibid, 200.

21 Ibid, 201.

22 Tay-Sheng Wang, 'The Legal Development of Taiwan in the $20^{\text {th }}$ Century: Toward A Liberal and
}

ancient tradition of mediation and dispute resolution in China.

\section{A look at modern mediation}

As explain above, that culture is actually has impact on how legal process and dispute resolution operates in each of the country, this section analyses how modern approach also contributes on country's legal process. How each country react on modern development towards their own legal process and alternative disputes resolutions.

\section{Today's China: Confucianism and Communism}

China today retains the widespread use of mediation, aided by Maoist approval of Confucian values. 'Maoist ideology has put enormous emphasis on mediatory justice, in many ways even more than [the attitudes found in the Qing dynasty]'. ${ }^{24}$ Mao adopted slogans based on Confucius in order to promote mediatory justice, for example 'mediation is the main thing, adjudication is secondary'. ${ }^{25}$ Communist China drew from the cultural ideals that came before, aiming to create 'socialism with Chinese characteristics'. Mediation in this context was highly valued because it maintained the values of collectivism and social harmony that is integral to achieving a united body politic. Hence, the way that the Chinese people have used and valued mediation in the current era has been essentially continued from the Qing dynasty, but for slightly different reasons.

The mediation that exists now, in socialist China, is inherently different to that

\footnotetext{
Democratic Country', (2002) 11 Pacific Rim Law and Policy Journal 531, 559.

23 Ibid, 531.

${ }^{24}$ Philip Huang, 'Court Mediation in China, Past and Present' (2006) 32 Modern China 275, 285.

25 Cohen, above $\mathrm{n} 4$.
} 
in the Qing dynasty. Huang terms this new mediation to be 'adjudicative mediation that is, mediation with adjudicative features, so long as it is not imposed against the will of a litigant. ${ }^{, 26}$ It also had distinct differences from the Qing law, and from the glimpses of Western law implemented by the Nationalists prior to 1949 , because it was more focussed on justice according to the ideal; 'from the masses, to the masses'. ${ }^{27}$ Following this ideal, the Civil Procedure Law of the People's Republic of China established the idea of circuit trial, where judges were given more of an active role investigating the truth at the grassroots level, and finding out if the dispute was worth resolving in order to preserve harmony in society. ${ }^{28}$ One example of this in action was a judge involved in a dispute about trees on the boundary of the two parties' residential blocks, which ended up in a physical fight leaving the plaintiff with a concussion. After the village leaders had attempted to mediate, the judge got involved directly and spoke with witnesses to the fight, privately visiting both of the parties and hearing their versions of the facts. ${ }^{29}$ According to Huang, this allowed him to speak 'with all the authority not only of the court, but also of the knowledge gleaned from his thorough investigation of the facts' ${ }^{30}$ Mediation, as such, has become a more involved process that even further emphasises the ideal of social harmony and compromise through the actions of the investigative judiciary.

Nationalist and subsequently Socialist government policy also changed the way mediation was treated, in that it brought

\footnotetext{
${ }^{26}$ Huang, above n 25, 276.

27 Ibid, 286.

28 David Kwok, 'The (im)propriety of judicial mediation' (2015) 26 Australian Dispute Resolution Journal 210, 211-2.
}

Codes from a Civil Law system and courts to adjudicate on those Codes. ${ }^{31}$ This meant that there was a brand new system in which mediation occurred alongside a Westernstyle court instead of an Imperial court that was only located in central cities of each province. Codified civil laws regarding divorce, rights of ownership and other 'petty' matters as they were in the Qing dynasty, began from a rights perspective rather than an Emperor's perspective and as such changed the way that Chinese people used the law and regarded their disputes. ${ }^{32}$ In modern China, 'court mediation is becoming a less and less prominent part of the total justice system, because of the mounting caseloads and changing ideas about the rule of law' ${ }^{33}$. China in the new century is moving away from a rule of man approach to a rule of law approach, and as such people in China can more easily use their court system to resolve disputes because it is more accessible, and more focussed on them and their rights than the Imperial autocratic manifestation of the law. The responsibility of Chinese people in the modern legal context is therefore no longer to resolve disputes between themselves in order to avoid embarrassment and inconvenience, but it is instead to access a court system that will, at least theoretically, protect their rights.

All of the People's Republic of China's initiatives and Codes are still very recent, but it is clear that a more accessible court system is fostering a move away from the traditional reliance on mediation and distaste for the litigation process. Modern Chinese law and mediation practices have taken on a heavy

\footnotetext{
29 Huang, above n 25, 294-5.

30 Ibid, 295.

31 Ibid, 297.

32 Ibid, 297-8.

33 Ibid, 298.
} 
formalist influence, although they still hold distinct Confucian influence and characteristics.

\section{Taiwan Today: Journey to the West?}

When the Nationalists fled the mainland in 1949, they brought with them a legal system largely modelled on modernised Japan that was never implemented in the mainland due to recurrent war. ${ }^{34}$ Because of this, 'the old Japanese code was substantively preserved in Taiwan' ${ }^{35}$ not intentionally, but by the fact that the Nationalists had created a significantly German civil system with the Japanese modern system in mind. Taiwanese people therefore had more than twenty years experience with a German based system, and were at least somewhat used to the way that it operated to resolve disputes. ${ }^{36}$

The Japanese system was not fully preserved in the sphere of mediation, because the Nationalists brought with them a Chinese county mediation system and changed the mediators from administrative officials to local people and others who were not in official positions. ${ }^{37}$ The Act of Town Mediation in 1955 established this type of County mediation. ${ }^{38}$ It created a more adjudicative mediation, similar to that introduced in Maoist China. It included mechanisms allowing the judicial oversight of mediation, in that there was now an appeal system that did not exist in the Japanese style of administrative mediation. ${ }^{39}$ Further amendments to Town Mediation since 1955 have promoted an impartial committee of mediators, and reformed the enforceability of

\footnotetext{
${ }^{34}$ Lin, above n 3, 203.

35 Wang, above n 23, 537.

36 Ibid, 556.

37 Ibid, 558

38 Lin, above n 3, 205.

39 Ibid, 205.

40 Ibid, 206.
}

decisions to ensure that parties will follow the result that is mediated for them. ${ }^{40}$ Statistics from Taiwan's Ministry of the Interior state that 'cases of town mediation have increased from around 45,000 in 1991 to 112,000 in $2008,{ }^{41}$ This has not been attributed to the modernised system in Taiwan, but more to the fact that there was a notable increase in the use of criminal mediation, and the increased occurrence of traffic accidents. ${ }^{42}$

While there had been marked growth in the way that Taiwanese people accessed the courts in the Japanese colonial period, the increased Western influence brought by the Nationalists led to an even stronger increase in the number of lawsuits brought to the courts. ${ }^{43}$ This increase was also aided by the urbanisation of Taiwan, making it more difficult to find a mediator substantially connected to each of the parties, as well as the capitalist economy and social context creating more complex disputes that require the assistance of a court. ${ }^{44}$ Unlike the old Chinese agricultural society that was the foundation of face-to-face relationships and mediation styles, the increased urbanisation and industrialisation of Taiwan meant that relationships and ways to maintain those relationships had substantially changed and could no longer be resolved so informally. ${ }^{45}$ There is still a distinct Confucian influence, since Taiwan is still a 'relationship-driven society' that judges fairness in the context of social relations instead of strict justice under law. ${ }^{46}$ While that influence is not as clearly followed as it is in the People's Republic of

\footnotetext{
41 Ibid, 206.

42 Ibid, 206.

43 Wang, above n 23, 559.

44 Ibid, 559.

45 Lin, above n 3, 204.

46 Ibid, 207.
} 
China, the way that mediators and adjudicators judge disputes is still informed by Confucian thought that aims to preserve harmony and relationships even in an urbanised, democratic and capitalist society.

Taiwan sits firmly between Japan and Mainland China, physically and legally. It is still strongly connected to Imperial China through its cultural connections and schools of thought, despite being heavily Westernised through the legal systems brought by the Japanese colonists and the Nationalists that were both based on the German Civil Codes.

\section{Modern Australia: Moving forward?}

Since the beginning of the ADR movement in1970s United States, when a former Chief Justice asked 'Isn't there a better way?'47, Australia has focussed on implementing measures to ensure that cost, time and energy is saved in the court system to better the sense of justice and satisfaction in users of the court process. Up to the present day, 'ADR processes are increasingly being used as a [legitimate] alternative to litigation in many types of disputes ${ }^{38}$, and there is now court-related resolution mechanisms in every court and tribunal in Australia, as well as community and private mediation in all Australian jurisdictions. ${ }^{49}$ One example of the way that mediation has been introduced in Australia is the Cooperative and Community Housing Act 1991 (SA) which states that appeals from disputes under the legislation can only be determined if there is found to be a genuine attempt at mediation first. ${ }^{50}$ This type of

\footnotetext{
47 Kwok, above n 29, 214.

48 Tina Popa, 'All the way with ADR: Further endorsement of ADR in litigation' (2015) 26 Australian Dispute Resolution Journal 218, 218.

49 Alexander, above n 6, 2.
}

mandatory mediation is most common in Australian jurisdictions, used to directly combat the heavy caseload of high volume courts. The widespread presence of ADR in Australia attributable to a few factors, namely the clogged courts, high costs of litigation and dissatisfaction with the court process as well as the pro-active promotion of ADR methods in the wider community. ${ }^{51}$ The most interesting example of the Australian promotion of mediation is the way that it has been incorporated into law scholarship, in that some kind of study of ADR processes is compulsory in most Australian law degrees. This has fostered a growing support base for ADR because it has become less of a foreign idea to a common law student, and more of a solution to the problems that the common law has faced since the times of the King's Bench.

There is still, however, harsh criticism of the way that mediatory processes impact the way that our common law system is used in practice. The English case of Jones $v$ National Coal Board ${ }^{52}$, involving a trial judge who was 'anxious to understand the details of this complicated case... anxious to investigate' and held to be intervening excessively sets out the image of an ideal judge to be more of a 'passive umpire' than a conscientious resolver like the Chinese mediators. ${ }^{53}$ Although this case was decided in 1957, and the judicial role has transformed significantly since then, the case still represents the attitudes of a significant school of thought that criticises ADR methods. Kwok points out the 'judges are now given powers they never had before to become

\footnotetext{
50 Ibid, 12.

51 Ibid, 7.

52 [1957] 2 QB 55.

53 Kwok, above n 29, 213-4.
} 
interventionists. Whether this is a good thing is debatable'. ${ }^{54} \mathrm{He}$ says this because the foundation of the Australian image of 'fairness' is the idea of impartiality, theoretically a judge must be a completely neutral figure that does not inquire into the matters of the case but rather decides on the facts presented to them. This foundation is not helpful to the development of mediation because it suggests that a judge who relaxes their adjudication in favour of a more efficient process is not really adjudicating at all.

One significant reason that Australia has been so receptive to $\mathrm{ADR}$ is that our position in the Pacific Basin means that there is a direct influence of cultures such as China who are less accustomed to adversarial dispute resolution, that allow us to see how alternative dispute resolution methods can work in different contexts. ${ }^{55}$ The effect of comparative law is often underestimated, and in modern multicultural Australia it does play at least a small role in the way that the legal system is used. This is mainly because there are people with all kinds of experiences with diverse legal practices who must also use the Australian court process, and a court is really only made up of the people who use it. Just like in Taiwan, the experiences and attitudes of the people themselves rather than the regime above them dictate how mediation and court processes are used.

\section{Who's law is it?}

\section{Scenes from a hat: Mediation takes many forms}

Just like a person can interpret an instruction in many ways, the way that a legal system receives and interprets a concept is totally unique. The Chinese, Taiwanese and

\footnotetext{
54 Ibid, 216.

55 Dwight, above n 1, 4.
}

Australian legal systems have all engaged with some kind form of mediation and ADR process, but they have all engaged in different ways according to their cultural foundations and social experiences.

One obvious difference between Australia and China/Taiwan is the fact that we are a common law country and the others are civil law countries. The difference is significant because the civil law tradition is usually seen as restraining the development of mediation, in that it is based on the idea that all laws are contained in codes. ${ }^{56}$ This is certainly the case in Germany, however in China and Taiwan the experience has been completely different. The reason for this lies in the way that mediation is enshrined in the Chinese culture, as a way to preserve social order in the same way that the civil code does in Germany - the birthplace of China and Taiwan's current system. In Australia it has been proposed that the reason why mediation is so well received is because the common law allows for flexibility and the interaction of many different legal mechanisms with the mainstream court system. ${ }^{57}$ While this is true, a common law system in general is not conducive to a healthy mediation system because of the way that 'fairness' is perceived; as inherently impartial. The common law and the civil law therefore play a distinct role in how mediation is treated, but this is often undercut by the culture that surrounds the legal system. I contend that while civil law systems in the West are generally more resistant to ADR processes, it is important to recognise those countries like China in discussions of how ADR is received in different cultural contexts. To say that civil law countries do not accept mediation is a narrow view of the diverse range of civil law

\footnotetext{
56 Alexander, above n 6, 3.

57 Ibid, 20-21.
} 
systems that exist in many different cultures, particularly in the Asia-Pacific region.

Taiwan's system, inherited from almost everywhere, is a great example of how even legal systems become globalised. The way that mediation is conducted in a Western structure with a distinct Taiwanese flair shows how the people in a society as well as its rulers dictate how legal processes really operate. Although Taiwan's civil codes are modelled on Germany, and are in fact very similar to other Western civil law countries, its distinct Confucian and Japanese influences dictate how the law operates in practice. It is especially unique when compared with China and Australia because it provides an example of a kind of midpoint between the two; where China is unapologetically Chinese with Western influence and Australia is a fiercely common law system with distinct Asian influences. Taiwan then falls in the centre of this spectrum, being the convenient experimental society in which Japan, the Chinese Nationalists and other Western occupiers could place their ready-made modernised legal systems. The way that the Taiwanese value mediation in a their capitalist, civil law society is a clear reflection of its complex history.

\section{CONCLUSIONS AND SUGGESTIONS}

The comparison between the way that Australians, Taiwanese and Chinese treat the mediation process reveals just how important culture is when examining legal process. 'It is nothing less than misleading to consider mediation as a universal process in isolation from its context ${ }^{58}$, and further it is misleading to consider the Western experience in isolation from the rest of the world - especially when Asian countries have such a unique experience with mediation and ADR processes. When considering the East in discussions of ADR, although it seems that our mediation systems are moving in opposite directions, it is obvious that we are really working towards the same goal of justice and access to the court systems. The perceptions of justice from those three contries may be different, and the way that each contry's court systems operate are different too, but ultimately the law is about resolving disputes in a way that is compatible with a body of people. The question was never really who's law mediation was, but rather how can we learn from other experiences with mediation and incorporate them into our own system to better facilitate dispute resolution in our own society.

\section{REFERENCES}

\section{Books}

Courts and Tribunals Judiciary, History of the Judiciary (2017)

Merrils, J.G, Alternative Dispute Resolution, (1999)

Shaw, Malcolm, International Law, (1998)

\section{Journal Articles}

Alexander, Nadja 'What's Law Got to Do With It? Mapping Modern Mediation Movements in Civil and Common Law Jurisdictions' (2001) 13 Bond Law Review 1

${ }^{58}$ Ibid, 1. 
Cohen, Jerome Alan 'Chinese Mediation on the Eve of Modernization' (1966) 54 California Law Review 1201

Dwight, Peter 'Commercial Dispute Resolution in Australia: Some Trends and Misconceptions' (1989) 1 Bond Law Review 1

Feng, Yujun 'Legal Culture in China: A Comparison to Western Law' (2010) 16 Revue Juridique Polynesienne 115

Huang, Philip 'Court Mediation in China, Past and Present' (2006) 32 Modern China 275

Kwok, David 'The (im)propriety of judicial mediation' (2015) 26 Australia Dispute Resolution Journal 210

Lin, Yun-Hsien Diana 'Civil Mediation in Taiwan: Legal Culture and the Process of Legal Modernisation' (2011) 6 University of Pennsylvania East Asia Law Review 191

Popa, Tina 'All the way with ADR: Further endorsement of ADR in litigation' (2015) 26 Australian Dispute Resolution Journal 218

Wang, Tay-Sheng 'The Legal Development of Taiwan in the $20^{\text {th }}$ Century: Toward a Liberal and Democratic Country' (2002) 11 Pacific Rim Law and Policy Journal 531

\section{Legislation}

Civil Procedure Law of the People's Republic of China

Cooperative and Community Housing Act 1991 (SA)

The Act of Town Mediation (Taiwan)

\section{Cases}

Jones v National Coal Board [1957] 2 QB 55

\section{Internet}

Kirby, Michael 'ADR and Different Legal Cultures' (Speech delivered at the Arbitrators' and Mediators' Institute of New Zealand, Institute of Arbitrators and Mediators Australia Conference, Christchurch NZ, 6 August 2010) http://www.michaelkirby.com.au/imag es/stories/speeches/2000s/2010_Speec hes/2476-AMINZ--IAMA-CONF2010-CHRISTCHURCH-NZ.pdf 